\title{
Teaching Practice Exercise for Education Students in Nigerian Universities: Challenges and the Way Forward
}

\author{
Haastrup Timilehin Ekundayo Ph.D. \\ Department of Educational Foundations and Management, Faculty of Education, \\ Ekiti State University, Ado-Ekiti, Nigeria \\ email: haastrupt2006@yahoo.com
}

Hezekial Ogbomida Alonge Ph.D.

Department of Educational Studies and Management,Faculty of Education,

University of Benin, Benin-City, Nigeria

Adenike Olayinka Kolawole

Department of Educational Foundations and Management, Faculty of Education, Ekiti State University, Ado-Ekiti, Nigeria

\author{
Mrs. Stella K. Ekundayo \\ Department of Curriculum Studies, Faculty of Education, \\ Ekiti State University, Ado-Ekiti, Nigeria
}

\section{Doi:10.5901/mjss.2014.v5n9p486}

\section{Abstract}

\begin{abstract}
The purpose of this study was to find out the various problems student-teachers face during the teaching practice exercise and proffer possible solutions. The study adopted the descriptive research of the survey type. The population consisted of all the lecturers and students of the Faculty of Education in three universities namely, Ekiti State University, Ado Ekiti; Adekunle Ajasin University, Akungba-Akoko and University of Benin, Benin-City. The sample was however made up of 69 lecturers and 244 students across the three universities. A self designed instrument tagged 'Teaching Practice for Education Students in Universities Questionnaire (TPSIUQ)' was used to collect data for the study. The instrument was validated by research experts in educational planning and in test and measurement in Ekiti State University, Ado Ekiti. Cronbach Alpha method was used to determine the reliability coefficient which stood at 0.79 . The finding showed, among other things, that the student teachers face accommodation problem most especially when they are posted outside the university town. The result further showed that lecturers and students do not differ in their perception of the problem being faced by the student teachers. Based on the findings of the study, it was recommended that there should be proper orientation for the student teachers before going on teaching practice exercise. It was again recommended that the university authority should give the student teachers financial support for their upkeep during the exercise.
\end{abstract}

Keywords: teaching practice, prospective teachers, education, experienced lecturers, Nigerian universities

\section{Introduction}

Teaching is an activity performed by an individual (who is the teacher) whose intention is to bring about learning. Teaching is an exciting and rewarding activity that is very demanding. Teaching requires that the practitioners clearly understand what should be done to bring about the most desirable learning in the learners and be highly proficient in the skills necessary to carry out this tasks. The role of teachers in sustainable development cannot be quantified, especially in training personnel in various areas of the workforce. However, according to Nwanekezi, Okoli and Mezieobi (2011), the teacher needs to be properly educated and trained for professional efficiency and inculcated with a positive attitude that will enable him/her go through the training properly and come out well equipped for the responsibility ahead.

To provide professional education for teachers, colleges of education have been established almost all over the world (Azeem, 2011). In Nigeria, teacher education programme exists in consonance with the various levels of education 
that is NCE and B.Ed. for colleges of education and universities respectively. All the teachers training institutions are not imparting theoretical but also practical knowledge and skill in teaching different subject to prospective teachers. At the end of the session, teaching practice is carried out for practical application of theoretical understanding about different teaching methods.

Teaching practice occupies a key position in the teacher education programme. It is an integral part of the teacher education programme which is geared towards preparation of new entrants into the teaching profession. According to Afolabi (1999), teaching practice exercise is to acquaint student teachers with the practical knowledge of teaching and learning process including lesson plan preparation, presentation, class management, communication skills, evaluation and the required personality of professional teachers. Nwanekezi, et al (2011) remarked that teaching practice is the name of the preparation of student - teacher for teaching by practical training.

From the foregoing, it can be inferred that teaching practice is a school-based internship programme with the main aim of introducing prospective teachers to teaching and its routine under the guidance of qualified professionals to develop skills, attitudes and competence in the profession. The exercise provides trainees the opportunity to utilize the various teaching methods in actual classroom conditions under constant supervision of competent and experienced teachers.

The concept of teaching practice is made clearer by looking at the objectives of the exercise as enumerated by Akbar (2002). Some of which are:

1. To provide prospective teachers with the opportunity of establishing an appropriate teacher pupils relationship.

2. To provide an opportunity of evaluating the students potential as a teacher and suitability for the teaching profession.

3. To develop personal relationship with others administrators, teachers, parents and students.

4. To provide the future teachers with experience in school to overcome the problem of discipline and enable him/her develop method of control.

5. To provide an opportunity to put theories into practice and develop deeper understanding of educational principles and their implication of learning.

6. To enable the student teachers effectively plan and prepare lessons.

7. To develop skills in the use of fundamental procedures, techniques and method of teaching.

8. To develop desirable professional; interest, attitudes and ideas relative to teaching profession.

9. To enable students acquire desirable characteristics/traits of a teacher and to display appropriate behaviour.

10. To provide student teachers with opportunity to have teaching evaluation and to gain from constructive criticism.

11. To provide an opportunity for self evaluation and to discover one's strength and weakness.

12. To develop skill in future teachers related to teaching like fluent speaking meaningful reading, using blackboard and other teaching materials.

Currently, in Nigerian universities, teaching practice is a compulsory course in the faculties of education which forms part of the prerequisites for graduation. However, observations have shown that there is a decline in the quality of teaching practice being offered in the universities now. It appears that teaching practice as being currently run in the universities is considered as inadequate. There seems to be a lot of problems facing the prospective teachers in the course of carrying out the teaching practice exercise that seem to affect the effectiveness of the student teachers.

Personal experience has shown that some of these problems are student teacher related problems while some are institutions (universities) related problems and some are school of teaching practice related problems. For instance, Idowu (2000) remarked that the programme is beset with a multiplicity of problems and a lot of difficulties confronting student-teachers cooperating teachers as well as the cooperating schools and the supervisor. The author identified some of the problems to include psychological makeup of the trainees, pedagogical preparations, classroom adaptation, and mode and means of assessment.

Jekayinfa, Yahaya, Yusuf, Ajidagba, Oniye, Oniyangi and Ibraheem (2012) have commented on the quality of teaching practice. The authors lamented that the quality of the exercise as being currently run is inadequate. Ogonor and Badmus (2006) submitted that student teachers are not often properly groomed to put into practice current pedagogy and interactive skills that has been theoretically learnt.

Studies have also revealed some other problems that bedeviled the teaching practice exercise for example, Ogonor and Badmus (2006) lamented that teachers of partnership schools did not provide specific aid to student teachers to improve their teaching skills and strategies. Nakpodia (2011) remarked that the periods of twelve weeks is too short as it does not provide the student teacher the ample opportunity to effectively gain the experience which the exercise is intended to encourage. The author remarked that some supervisor do not even have time to sit down and discuss their 
observations and comments with the student teacher. The short discussion between the supervisor and the studentteacher just after the lesson supervisor which should afford the student teacher the opportunity to appreciate his strengths and weaknesses are often ignored because the supervisor is often in a haste to move on to the next school.

Besides, Capel (1997) reported that student teacher feel nervous and restless when they are being observed, evaluated and assessed. Adekunle (2000) acclaimed that the unserious attitude of the secondary school students towards the exercise often results to the student teachers not gaining the skills, confidence and knowledge to cope with the classroom situations. Bhargava (2009) remarked that student teachers often complain that they forgot the content matter and feel nervous when their lecturers sit at the end of the classroom and observe. The author remarked that the behavior of student teacher changes, comfort level becomes low and they find themselves in artificial situation where their main consideration remains how to get good remarks in record files.

Studies have also shown that status and experience greatly influenced the way a person carries out assessment. Omosewo (2000), Kingundu and Nayimuli (2009) and Jekayinfa et al (2012) submitted in their various researches that job status and experience influenced assessment made by individuals.

\section{Purpose of the Study}

The purpose of this study was to examine the various problems student teachers face during the teaching practice exercise. The study was also designed to find out whether lecturers and students differ in their perception of the problems facing prospective teachers during teaching practice. The study also found out whether experienced and less experienced lecturers differ in their perception of their problems facing student teachers. The study however made recommendations based on the findings of the study.

\subsection{Research Question}

The following research question was raised to guide the study.

1. What are the problems facing education students on teaching practice exercise?

\subsection{Research Hypotheses}

The following hypotheses have also been formulated to guide the study.

1. There is no significant difference in the perception of lecturers and students on the problems facing studentteachers.

2. There is no significant difference in the perception of experienced and less experienced lecturers on the problems facing student-teachers.

\section{Methodology}

A descriptive survey research design was used in the study. Population of the study consisted of all the academic staff and full time students in the faculty of education in Ekiti State University, Ado Ekiti, Adekunle Ajasin University Akungba Akoko and University of Benin, Benin City. The sample was made up of 69 lecturers and 244 students who were selected from the three universities using stratified and simple random sampling techniques.

A self-designed instrument tagged 'Teaching Practice for Education Students in Universities Questionnaire (TPESIUQ)' was used for the study. TPESIUQ has two sections: section A sought the background information of the respondents; section $B$ which was further divided into three sub-section sought information on the various problems facing the students on teaching practice.

The instrument was validated by research experts in Educational Planning, Tests and Measurement in Ekiti State University, Ado Ekiti. Cronbach Alpha method of reliability was used to determine the reliability co-efficient which stood at 0.79 .

The data for the study were analysed using both descriptive and inferential statistics. The descriptive statistics used include frequency counts and percentage scores while the inferential statistics employed was the t-test statistics. The hypotheses formulated were tested at 0.05 level of significance. 


\section{Results}

The results of the study were presented under two major sub-heading namely:

Descriptive analysis and testing of hypotheses as follows:

\section{Descriptive Analysis}

\subsection{Research question 1: What are the problems facing education students on teaching practice exercise?}

The answer to this research question is presented in three categories in line with the sub-sections of the section B of the questionnaire, namely:
i. Student-teacher related problems
ii. Institutions related problems
iii. The school of teaching practice related problems

Table 1: Student-teacher related problems

\begin{tabular}{|c|c|c|c|c|c|}
\hline$S / N$ & Items & Agree & $\%$ & $\begin{array}{c}\text { Dis- } \\
\text { agree }\end{array}$ & $\%$ \\
\hline 1. & There is accommodation problem for the student teachers in towns outside the university town & 246 & 78.6 & 67 & 21.4 \\
\hline 2. & Student-teachers find it difficult to instill discipline in the classes & 146 & 46.6 & 167 & 53.4 \\
\hline 3. & Student teacher have shallow knowledge of lesson note preparation & 131 & 41.9 & 182 & 58.1 \\
\hline 4. & There is non-challant of the student-teacher to give evaluation after teaching & 149 & 47.6 & 164 & 52.4 \\
\hline 5. & Student-teacher reject at will where they are posted for the teaching practice exercise & 238 & 76.0 & 75 & 24.0 \\
\hline 6. & Student-teachers feel nervous when they are being supervised by their lecturers/supervisors & 249 & 79.6 & 64 & 20.4 \\
\hline 7. & Student-teachers do not use various method of teaching in their exercise & 168 & 53.7 & 145 & 46.3 \\
\hline 8. & Student-teachers do not make good use of instructional materials & 135 & 43.1 & 178 & 56.9 \\
\hline
\end{tabular}

Results in table 1 shows that $79.6 \%$ of the respondents agreed that major problem that faces students during the teaching practice exercise is that the students teachers feel nervous when they are being supervised by their lecturers. Also, $78.6 \%$ of the respondents agreed that there is accommodation problem for the student teachers in towns outside the university town.

Of the respondents $76.0 \%$ agreed that students teacher reject at will where they are posted to for the teaching practice exercise. Besides, $53.7 \%$ of the respondents agreed that the student-teachers do not use various methods of teaching in the exercise.

Table 2: Institutions (universities) related problems

\begin{tabular}{|c|c|c|c|c|c|}
\hline$S / N$ & Items & Agree & $\%$ & \begin{tabular}{|c|} 
Dis- \\
agree
\end{tabular} & $\%$ \\
\hline 1. & The practicing period of 4 to 6 weeks is rather too short & 168 & 53.7 & 145 & 46.3 \\
\hline 2. & There is inadequate preparation of students for the teaching practice exercise & 231 & 68.1 & 100 & 31.9 \\
\hline 3. & Student-teachers are often posted to primary schools when they are being trained for secondary schools & 177 & 56.5 & 136 & 43.5 \\
\hline 4. & Proper orientation is not always conducted for the students before they go on teaching practice exercise & 174 & 55.6 & 139 & 44.4 \\
\hline 5. & $\begin{array}{l}\text { Micro-teaching that can help student-teachers gain confidence during teaching is not always conducted } \\
\text { for the student-teachers }\end{array}$ & 229 & 73.2 & 84 & 26.8 \\
\hline 6. & Supervisors/lecturers do not discuss their observation and comments with the student-teachers & 182 & 58.1 & 131 & 41.9 \\
\hline 7. & $\begin{array}{l}\text { Student-teachers do not have the opportunity to interact with partnership schools before the real } \\
\text { teaching practice exercise }\end{array}$ & 245 & 78.3 & 68 & 21.7 \\
\hline
\end{tabular}

Results in table 2 shows that among the institutions (universities) related problems that face students on teaching practice is that student teachers do not have the opportunity to interact with partnership schools before the real teaching practice exercise begin this was attested by $78.3 \%$ of the respondent. Also $73.2 \%$ of the respondent agreed that micro teaching that can help student teachers gain confidence during teaching is not always conducted for the studentteachers. 
Of the respondents, $68.1 \%$ agreed that there is inadequate preparation of students for the teaching practice exercise. While $58.1 \%$ of the respondents agreed that supervisors do not discuss their observations and comments with the students-teachers, $56.5 \%$ agreed that student-teachers are often posted to primary schools when they are being trained for secondary schools.

It was revealed in the table that $55.6 \%$ of the respondents agreed that proper orientation is not always conducted for the students before they go on teaching practice exercise. Again, $53.7 \%$ of the respondents agreed that the practicing period of 4 to 6 weeks is rather too short.

Table 3: School of teaching practice related problems

\begin{tabular}{|c|l|c|c|c|c|}
\hline $\mathbf{S} / \mathbf{N}$ & \multicolumn{1}{|c|}{ Items } & Agree & $\%$ & $\begin{array}{c}\text { Dis- } \\
\text { agree }\end{array}$ & $\%$ \\
\hline 1. & There are reported cases of student-teachers being rejected by schools where they are posted & 277 & 88.5 & 36 & 11.5 \\
\hline 2. & Some schools are not willing to distribute their schedule according to the needs of the student-teachers & 244 & 78.0 & 69 & 22.0 \\
\hline 3. & Instructional materials are not readily available in school & 252 & 80.5 & 61 & 19.5 \\
\hline 4. & There is poor learning environment in the practicing schools such as congestion, poor ventilation & 248 & 79.2 & 65 & 20.8 \\
\hline 5. & Teachers in partnership schools do not perform the roles of mentor & 193 & 61.7 & 120 & 38.3 \\
\hline 6. & Schools do give student-teachers subjects outside their area of specialization & 244 & 78.0 & 68 & 22.0 \\
\hline 7. & Students in partnership schools show uncooperative attitude towards student-teachers & 172 & 55.0 & 141 & 45.0 \\
\hline
\end{tabular}

Results in table 3 shows that among the problems being faced by student-teachers in the partnership schools is that student-teachers are often being rejected in the schools where they are posted. This was attested to by $88.5 \%$ of the respondents. Besides, $80.5 \%$ of the respondents agreed that instructional materials are not readily available in schools. While, $79.2 \%$ of the respondents agreed that there is poor learning environment in the practicing schools, $78.0 \%$ agreed that some schools are not willing to distribute their schedules according to the needs of the student-teachers as well as schools do give student-teachers subjects outside their area of specialisation.

Of the respondents, $61.7 \%$ agreed that students in partnership schools do not perform the roles of mentors. Again $55.0 \%$ agreed that student in partnership show uncooperative attitude towards the student-teachers.

\section{Testing of Hypotheses}

6.1 Hypotheses 1: There is no significant difference in the perception of lecturer and students on the problems facing student-teachers

Table 4: t-test showing the perception of lecturers and students on problems facing student-teachers

\begin{tabular}{|l|c|c|c|c|c|c|}
\hline \multicolumn{1}{|c|}{ Group } & $\boldsymbol{N}$ & Mean & SD & df & t-cal & t-tab \\
\hline Lecturer & 69 & 35.59 & 3.75 & \multirow{2}{*}{311} & \multirow{2}{*}{1.942} & \multirow{2}{*}{1.960} \\
\hline Student & 244 & 36.52 & 3.40 & & \\
\hline
\end{tabular}

$p>0.05$

Results in table 4 shows that t-cal (1.942) is less than t-table (1.960) at 0.05 level of significance. The hypothesis is therefore not rejected. This implies that there is no significant in the perception of lecturers and students on the problem facing student-teachers.

6.2 Hypotheses 2: There is no significant difference in perception of experienced and less experienced lecturers on the problem facing student-teachers.

Table 5: t-test showing teaching experience and lecturers' perception of problems facing student-teachers

\begin{tabular}{|l|c|c|c|c|c|c|}
\hline Group & $\boldsymbol{N}$ & Mean & SD & df & t-cal & t-tab \\
\cline { 1 - 5 } Less experienced & 39 & 35.51 & 3.92 & \multirow{2}{*}{67} & \multirow{2}{*}{0.419} & \multirow{2}{*}{1.980} \\
\hline Experienced & 30 & 35.90 & 3.48 & & & \\
\hline
\end{tabular}

$p>0.05$ 
Results in table 5 shows that $t$-cal $(0.419)$ is less than t-table (1.980) at 0.05 level of significance. The null hypothesis is therefore not rejected. This implies that there is no significant difference in the perception of experienced and less experienced lecturers on the problems facing student-teachers.

\section{Discussion}

The study revealed that one major problem that is student-related which face student-teachers is that they feel nervous and unstable when they are being supervised by their lecturers. The implication is that the students may not gain anything from their teachers whenever the latter's supervisor is around. This finding is in consonance with Capel (1997) and Bhargava (2009) who submitted that student-teachers become restless when they are being observed.

The study further showed that student-teachers face accommodation problem when they are posted outside the university town. This may account for why they reject their posting most especially when they are posted to schools outside the university town.

The results further revealed that student-teachers do not have the opportunity to interact with partnership school before the real exercise begins. Besides, micro-teaching is not always organized for the students. All these account for the inadequate preparation of the students for the exercise. This finding supports Ogonor and Badmus (2006) who submitted that student-teachers are not properly groomed to put into practice current pedagogy and interactive skills that have been theoretically learnt.

The study revealed that student-teachers are often being rejected in schools where they are posted. This seems to dampen the morale of the prospective teachers in schools where they are finally accepted. The study further showed that instructional materials are not readily available in the schools. This might not be unconnected with the level of funding of the schools. Besides, the finding revealed that teachers in partnership schools do not perform the role of mentors to the student-teachers. This submission agrees with Ogonor and Badmus (2006) who earlier remarked that teachers of partnership schools do not provide specific aid to student-teachers to improve their teaching skills and strategies. This seems not palatable for the system as mentoring received from the teachers goes a long way to increase the level of confidence and training by the prospective teachers.

In addition, the study showed that there is no significant difference in the perception of lecturers and students as regards the problem being faced by student-teachers. This finding is not surprising as both the students and lecturers alike are alive to the peculiarities of the teaching practice exercise. In the same vein, both experienced and lessexperienced lecturers do not differ in their perception of the problems faced by student-teachers.

\section{Conclusion}

Based on the findings of this study, it can be concluded that there are multi-faceted problems that face students on teaching practice exercise which have made the exercise ineffective as regards achieving the goals for which it was set up.

Besides, the inadequate preparation of the student-teachers towards the programme will not make the prospective teacher gain the necessary experience, skills and confidence they need when they eventually take up the teaching job.

\section{Recommendations}

Based on the findings of this study, the following recommendations were made:

1. There should be proper orientation for student-teachers before going on teaching practice exercise. During this orientation exercise, micro-teaching could be organised for the student-teachers. This will make them gain enough confidence during the real exercise.

2. That the university authority should give the student-teachers some financial support for their upkeep during the period of teaching practice. This will help ease their accommodation problem and as well reduce the rate at which students reject at will the school/places they are posted.

3. There is the need for an increase in the duration of the teaching practice exercise. A longer time would provide ample opportunity for the practice of professional activities associated with teaching by the prospective teachers.

4. Partnership school-heads should be given proper orientation on the need to fully integrate the studentteachers during the internship exercise.

5. The faculty authority should always find out earlier hand where the services of the student-teachers are 
needed to avoid the embarrassment of rejection.

\section{References}

Adekunle, M. O. (2000). The role of teaching practice in preparation of Social Studies teachers. Forum Academia. A multi-disciplinary journal of education. 2(1\&2):81-92.

Afolabi, S. O. (1999). The philosophy of supervision in education. Nigerian Education Digest. IV \& V (1): 39-48.

Akbar, R.A.(2002). A study of practice teaching of prospective secondary school teachers and development of practice teaching model. An unpublished Ph.D. thesis; Arid Agriculture University, Rawalpindi.

Azeem, M. (2011). Problems of prospective teachers during teaching practice. Academic Research international. 1(2): 308-316.

Bharagava, A. (2009). Teaching practice for student-teachers of B.Ed. programme: Issues, predicaments and suggestions. Turkish Online Journal of Distance Education. 10(2):1-7.

Capel, S.A. (1997). Changes in students' anxieties and concerns after their first and second teaching practices. Educational Research. 39: $21-28$.

Idowu, A. I. (2000). Teaching practice exercise: An overview. In A.I. Idowu, S.O. Daramola, A. S. Olorundare, O.O. Obiyemi, N.Y.S. ljaiya \& K. Lafinhan (eds.) A guide to teaching practice. Ilorin: Faculty of Education, University of Ilorin.

Jekayinfa, A. A.; Yahaya, I. A.; Yusuf, A.; Ajidagba, A. U.; Oniye, A. O.; Oniyangi S. O. \& Ibraheem, T. O. (2012). Lecturers' assessment of teaching practice exercise in Nigerian universities. Journal of Education and practice. 3(4): 79-85.

Kiggundu, E. \& Nayimuli, S. (2009). Teaching practice: A make or break phase for student-teachers. South African Journal of Education. 29: 345-358.

Nakpodia, E. D. (2011). Teacher and the student practice teaching programme in Nigeria educational system. International Journal of Educational Administration and policy studies. 2 (3): 33-39.

Nwanekezi, A. U.; Okoli, N. J. \& Mezieobi, S. A. (2011). Attitude of student-teachers towards teaching practice in the University of PortHarcourt, River State, Nigeria. Journal of Emerging Trends in Educational Research and Policy. Studies. 2(1): 41-46.

Ogonor, B. O. \& Badmus, M. M. (2006). Reflective teaching practice among student-teachers: The case in tertiary institutions in Nigeria. Australian Journal of Teacher Education. 31 (2): 1-11.

Omosewo, E. O. (2000). Guideposts in teaching physics at the senior secondary level. In A. I. Idowu, S. O Daramola, A. S. Olorundare, O. O. Obiyemi, N. Y.C. ljaiya \& K. Lafinhan (eds) A guide to teaching practice. Ilorin: Faculty of Education, University of Ilorin. 